\title{
Marketing Pattern, Value Addition and Major Constraints of Marigold Production in Surajpur District of Chhattisgarh, India
}

\author{
Yogesh Kumar Sai ${ }^{*}$, Shashank Sharma ${ }^{2}$, Anjali Verma ${ }^{2}$ and Yogeshwari Sahu ${ }^{2}$ \\ ${ }^{1}$ Department of Agri-Business \& Rural Management, ${ }^{2}$ Department of Agricultural Economics, \\ College of Agriculture, IGKV, Raipur, (CG), India \\ *Corresponding author
}

\section{A B S T R A C T}

Ke y w o r d s
Marketing channels,
Random
proportionate
method, Producer,
retailer, Consumer

\section{Introduction}

Marigold, belonging to family Asleraceae, is an important and popular flower of India and ranks third in number after roses and chrysanthemum. It is the native of America. Marigold is a high value and labor intensive crop and it is cultivated by most of the farmers on small scale. The area under marigold has increased from 1961.45 ha to 2145.70 ha in Chhattisgarh during the year of 2010-2011 and 2011-2012 (Anonymous
The present study was based on Performance of Pilkha Agro Producer Company Limited Silphili: A Case Study of Marigold production in Surajpur district of Chhattisgarh. 100 marigold farmers were selected by random proportionate method from the district. The primary data was collected from the marigold producers through personal interview method with the help of well-prepared questionnaire for the production and marketing year for kharif marigold 2016-17. The numbers of house hold is taken on category wise was 48 Marginal and 52 small farmers. The overall marketable surplus of marigold was observed as 84.16 quintal. Three marketing channels were observed in the sale of marigold viz., Channel-I: producer-consumer, Channel-II: producer-retailer-consumer and ChannelIII: producer-wholesaler-retailer-consumer. It was found that the price received by the marigold producer was Rs. 2300 per quintal, Rs. 2650 per quintal, Rs.3040 per quintal in channel -I, channelII and channel-III respectively. Producer's share in consumer rupee was highest in channel-I (99.13\%).The study suggested that efforts should be made to increase the area, production and productivity of marigold by providing good quality planting material, Infrastructure and value addition, improved technology for marigold production along with proper package and practices of floricultural crops for better flower management, cold storage and value addition in marigold flower can significantly increase its marketing and profitability on sales. 
During the same period, there was 7130.40 hectares area of flower and the production of flower was 26603.96 metric tons (Anonymous, Agriculture Ministry database). About 248.51 thousand hectares area was under Cultivation in floriculture in 2014-15.

Production of flowers is estimated to be 1,685 thousand tones loose flowers and 472 thousand tones cut flowers in 2014-15. Flowers occupy an important position in today's life. Flowers are required for religious festivals, marriages and other social gatherings, to greet the sick as well as to offer condolences. Flowers were grown at home for daily worship as well as for decoration purposes.

\section{Materials and Methods}

Chhattisgarh state consists of 27 districts, out of which Surajpur district was selected purposively for the present study. The 100 marigold farmers were selected by random proportionate method from the district.

The numbers of house hold is taken on category wise was 48 Marginal and 52 small farmers. The methodology employed for the present study mainly consisted of structured interview farmers involved with floriculture. Simple average and percentage method were used for analysis the collected data.

\section{Primary data}

The primary data was collected from the marigold producers through personal interview method with the help of well prepared questionnaire for the production and marketing year for kharif marigold 2016-17. The methodology employed for collection of primary data in the present study mainly consisted of structured interviews with farmers from Pilkha Agro Produce Company Limited.

\section{Secondary data}

The secondary data were collected through various sources like Government Site and other Non-Government organization.

\section{Period of study}

The detail enquiry was done for the year 2016-17.

\section{Analytical tools}

Simple average and percentage method was used to analyze the collected data.

\section{Analysis of data}

In order to fulfill the objectives of the study, the collected data was analyzed by using appropriate techniques and tools like marketing cost, marketing margin, price spread and marketing constraints.

\section{Results and Discussion}

\section{Marketing pattern and value addition of marigold}

\section{Marketing of marigold}

Like other agricultural commodities, marketing is playing very important role for the disposal of Marigold. The Raipur district of Chhattisgarh lacks of infrastructural development for the marketing of agricultural commodities especially for the flowers.

The Mundra, Raveli and Bhatagaon villages of the study area were situated in adjoining areas of Raipur having market near them but have unorganised market. During the course of study, producers, village merchants, wholesalers and retailers were generally engaged in assembling of Marigold and their marketing (Table 1). 


\section{Producers}

Marigold growers dispose their produce by themselves in Raipur flower market. It has been observed that about 70-80 per cent of the total produce was assembled by the growers themselves. Generally, the farmers of the nearby villages bring their produce to sell in the market in order to secure better prices. Small producers consider it better to sell their produce in the village to avoid deception existed in the marketing at Raipur flower market.

\section{Wholesalers}

Mostly, Marigold producers were sold their produce to wholesalers in market. After purchase the wholesale traders transfer the product to other district markets or at processing units.

\section{Retailer}

The retailer is the last intermediary in market. The retailer purchases the Marigold in market by farmers and sold out them by to various small markets at their own prices.

\section{Marketing channels and cost of marigold}

There were three types of marketing channels identified, in the study area (Table 2). Those which are as follows:

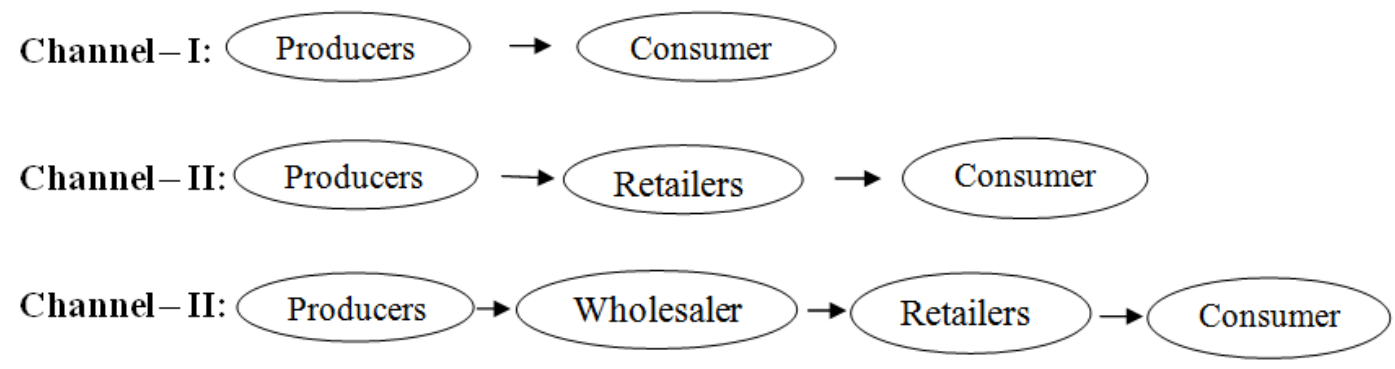

The marketing charges paid by the Marigold flower producer to the agents for different operations in Channel-I, which was worked out and found to be Rs. 2300, per quintal. The marketing charge paid by the marigold producer to wholesaler and retailer (channelII) was Rs. 2650 per quintal, respectively. Total marketing charges were higher being Rs.120 per quintal in channel-II. In channel III the total marketing cost incurred (channel III) was 3040 Rs/q. Therefore, producer has paid (Table 3-6).

\section{Disposal pattern of marigold}

Table-4 shows the disposable pattern of the marginal through 3 channels. For marginal farms, the total production 57.90 qt. has sold out of which 7.82was sold through channel I, 34.28 qt. was sold through II and 15.8qt.was sold through channel III. For small farms, total production was sold, out of which 14.56qt., 6379qt. and 51.67qt. was sold through channel I, channel II and channel III respectively overall 11.19qt.,49.04qt.and 33.74 qt. were sold through channel I, channel II and channel III respectively.

\section{Value addition of marigold flower}

This chapter was concerned with the assessment of value addition by marigold producers. Value addition was mainly interpreted as the difference between the total expenses involved in making or buying of a commodity and the total revenue accruing 
from its sales, Value addition activities were mainly concerned with the change of utilities. For those reasons this chapter goes through the cost and returns at different levels that were incurred and obtained by flower producers finally estimation of value addition of marigold.

Large size marigold garland was profitable than small size garlands. The net profit for large garland of marigold was Rs. 11 and the B.C ratio were 1:1.57 respectively.

\section{Problems faced in production, marketing} and value addition by growers

The problems of production and marketing arise when the objectives of production and marketing are constrained to be achieved. For the sake of convenience, the problems faced by the selected flower farmers in the study area have been categorized under three general groups such as economic, technical and marketing problems (Table-6). The economic problems that prevailed in the study area were high price of fertilizer and manure.
The study revealed that the high price of fertilizers and insecticides was the major problem of the farmers got IIIrd rank and Lack of labour got VIth rank on overall farms. The technical problems presented in the study area were Attack by pest and diseases IXth rank, Lack of scientific knowledge and training IVth rank, Environment related problem VIIth rank and Instability in yield got XIth rank.

The major marketing problems encounter in the study area on overall farms were Low demand for flowers in some seasons IInd rank , Low market price Ist rank, Lack of market information VIIIth rank, Price fluctuation Vth rank, Lack of storage facility XIth rank and Delay in Payment Xth rank .

Value addition is one of important task which performed after harvesting of the crop to increases their shelf life, time utility and price of the flower. But in study area farmers faces lack of knowledge regarding value addition of the flower by different extension institutes. And it ranks XIV among all problems.

Table.1 Average costs and margins of various agencies in the marketing of marigold per quintal through Channel- I

\begin{tabular}{|l|l|c|}
\hline S.No & Particulars/ Market functionaries & Amount (Rs./q) \\
\hline 1. & Marketing costs at producer level & \\
\hline 2. & Loading, Unloading, Weighting & 00 \\
\hline 3. & Transportation charge & 00 \\
\hline 4. & Other & 20 \\
\hline 5. & Sub total & 20 \\
\hline 6. & Producers sale price & $2280 / \mathrm{qt}$. \\
\hline 7. & Net price received & 99.13 \\
\hline 8. & Producers share in consumer rupees (\%) \\
\hline
\end{tabular}


Table.2 Costs and margins born by various agencies in the marketing of marigold per quintal through channel- II

\begin{tabular}{|l|l|c|}
\hline S/No. & Particulars/ Market functionaries & Amount (Rs./q) \\
\hline 1. & Marketing costs incurred by producer level & 20 \\
\hline & Loading, Unloading,Weighting & 20 \\
\hline & Transportation charge & 10 \\
\hline & Other charge & 50 \\
\hline & Sub total & 2200 \\
\hline & Producers sell price & 2150 \\
\hline 2. & Net price received & \\
\hline & Cost incurred by Retailer & 20 \\
\hline & Loading, Unloading,Weighting & 40 \\
\hline & Transportation charge & 10 \\
\hline & Market Fee & 70 \\
\hline & Sub Total & 10 \\
\hline & Marketing cost & 60 \\
\hline & Net price received & 2650 \\
\hline & Retaiars sell price /consumer purchase price & $480 \mathrm{qt}$. \\
\hline & Net Margin of Retailar & $81.13 \%$ \\
\hline & Producer share in consumer Rupees & \\
\hline
\end{tabular}

Table.3 Costs and margins born by various agencies in the marketing of marigold per quintal through Channel- III

\begin{tabular}{|l|l|c|}
\hline S/No. & Particulars/ Market functionaries & Amount (Rs./q) \\
\hline $\mathbf{1 .}$ & Marketing costs incurred by producer level & 20 \\
\hline & Loading, Unloading,Weighting & 150 \\
\hline & Transportation charge & 00 \\
\hline & Other including charge & 170 \\
\hline & Sub total & 2030 \\
\hline 2. & Net price received & \\
\hline & Cost incurred by wholesellar & 20 \\
\hline & Loading,Unloading,Weighting & 40 \\
\hline & Transportation charge & 10 \\
\hline & Other including mandi fees & 70 \\
\hline & Sub Total & 2610 \\
\hline & Wholesaler sell price/Retailer purchase price & 340 \\
\hline & Net margin wholesaler & 2650 \\
\hline \multirow{2}{*}{ 3. } & Retaiars sell price /consumer purchase price & \\
\hline & Cost incurred by retailer & 20 \\
\hline & Loading, Unloading, Weighting & 40 \\
\hline & Transportation & 10 \\
\hline & Other including bazaar fees & 3040 \\
\hline & Retailers sell price /consumer's purchase price & 360 \\
\hline & Retailer net Margin & 66.77 \\
\hline & Producer share in consumer Rupees & \\
\hline & & \\
\hline
\end{tabular}


Table.4 Disposal pattern of marigold (qt/farm)

\begin{tabular}{|l|l|l|l|l|l|}
\hline Farm Size & $\begin{array}{l}\text { Total } \\
\text { production }\end{array}$ & Total sold & Channel-I & Channel-II & Channel-III \\
\hline Marginal & 57.90 & 57.90 & 7.82 & 34.28 & 15.8 \\
& $(100)$ & $(100)$ & $(13.51)$ & $(59.20)$ & $(27.29)$ \\
\hline Small & 130.02 & 130.02 & 14.56 & 63.79 & 51.67 \\
& $(100)$ & $(100)$ & $(11.20)$ & $(49.06)$ & $(39.74)$ \\
\hline Overall & 93.96 & 93.96 & 11.19 & 49.04 & 33.74 \\
& $(100)$ & $(100)$ & $(11.91)$ & $(52.19)$ & $(35.91)$ \\
\hline
\end{tabular}

Table.5 Cost of production of 1 large garland of marigold

\begin{tabular}{|l|l|c|}
\hline S. No. & Description & Price(Rs) \\
\hline 1. & Raw material & 6 \\
\hline 2. & Labor and other charge & 1 \\
\hline 3. & Total cost & 7 \\
\hline 4. & Selling price $(1$ garland $)$ & 18 \\
\hline 5. & Net Income & 11 \\
\hline 6. & B:C Ratio & $1: 1.57$ \\
\hline
\end{tabular}

Table.6 Problems faced by the growers in production, marketing and Value addition of marigold

\begin{tabular}{|c|c|c|c|c|}
\hline Problems & Marginal & Smalll & Total & Rank \\
\hline \multicolumn{5}{|l|}{ Economic Problem } \\
\hline $\begin{array}{l}\text { High Price of fertilizers and } \\
\text { insecticides }\end{array}$ & 38 & 43 & 81 & III \\
\hline Lack of Labour & 40 & 47 & 87 & VI \\
\hline \multicolumn{5}{|l|}{ Technical Problem } \\
\hline Attack by pest and diseases & 32 & 37 & 69 & IX \\
\hline $\begin{array}{l}\text { Lack of scientific knowledge and } \\
\text { training }\end{array}$ & 43 & 34 & 77 & IV \\
\hline Environment related problem & 33 & 39 & 72 & VII \\
\hline Instability in yield & 18 & 21 & 39 & XII \\
\hline \multicolumn{5}{|l|}{ Marketing Problems } \\
\hline $\begin{array}{l}\text { Low Demand for Flowers in Some } \\
\text { Seasons }\end{array}$ & 41 & 47 & 88 & II \\
\hline Low market price & 46 & 48 & 94 & I \\
\hline Lack of market Information & 33 & 37 & 70 & VIII \\
\hline Price fluctuation & 35 & 44 & 79 & $\mathrm{~V}$ \\
\hline Lack of storage facility & 28 & 35 & 63 & $\mathrm{XI}$ \\
\hline Delay in Payment & 22 & 29 & 52 & $\mathrm{X}$ \\
\hline \multicolumn{5}{|l|}{ Value Addition } \\
\hline Lack of knowledge in this field & 13 & 23 & 36 & XIV \\
\hline
\end{tabular}


An efficient marketing channel and system is crucial for successful marketing of marigold in terms of yield and income. Proper marketing information and facilities will ultimately improvise the producer's share in consumer's price. Farmers are needed to be acknowledged with recent research techniques under this crop which will help them to improvise in production business. The researchers and extension agencies should contribute to narrow the gap between potential and actual yield.

\section{References}

Balamurugan, L., Jyothi, T. K. and Rajkumar. C. S. 2014. Production, Post-Harvest Handling And Marketing Of CutFlowers In Tamil Nadu, International Journal of Recent Scientific Research, 5(11): 2117-2122.

Dhilon, A., Khatkar, R.K. and Kumar, A .2005. Marketing Costs and Price Spread for Marigold Flower in Haryana. Agricultural Marketing,48(1):9-12.
Ingle, S. G., Pawar, B. R, Tawale, J. B. and Jagde, S. A. 2009. Marketing costs and price spread for kagda flower in Nanded district of Maharashtra. Agriculture Update 4(3\&4): 259-261.

Jahan, H. 2009. Production, post-harvestf handling and marketing of cut-flowers in Bangladesh: an agribusiness study. Saarc Journal of Agriculture, 7(2): 1-14.

Prajapati, P., Singh, A. and Jadhav, P.B. 2016. Value Addition In Floriculture Through Essential Oils, International Journal of Information Research and Review(IJIRR), 3(9): 2795-2799

Subramanyam, K. V. 1983. Grow Flowers for High Income Economic Analysis of Chrysanthemum and Marigold in Karnataka, Indian Horticulture, JulySept 43(3): 87.

Verma, H.K., Patel, B.M., Patel. J.K and Yadav, P. 2013. Constraints in adoption of marigold production technology. Hind Agricultural Research and Training Institute, 8(1\&2): 177-179.

\section{How to cite this article:}

Yogesh Kumar Sai, Shashank Sharma, Anjali Verma and Yogeshwari Sahu. 2020. Marketing Pattern, Value Addition and Major Constraints of Marigold Production in Surajpur District of Chhattisgarh, India. Int.J.Curr.Microbiol.App.Sci. 9(06): 3142-3148.

doi: https://doi.org/10.20546/ijcmas.2020.906.376 